\title{
Pemanfaatan Daun Kelor sebagai MP - ASI dalam Upaya Peningkatan Status Gizi Balita
}

\author{
Diah Atmarina Yuliani, Purwati, Isnaeni Rofiqoch \\ Email: yuliani_da@yahoo.com \\ Prodi Kebidanan D III, Universitas Muhammadiyah Purwokerto, Indonesia \\ Jl. Soepardjo Roestam Km. 7, Sokaraja, Purwokerto \\ Telp. (0281) 6844252, 6844253/Fax (0281) 637239
}

\begin{abstract}
Abstrak
MP-ASI merupakan proses peralihan dari susu menuju ke makanan yang semi padat. MP-ASI harus diperkenalkan dan diberikan secara bertahap baik bentuk maupun jumlahnya, sesuai dengan kemampuan pencernaan anak. ASI hanya memenuhi kebutuhan gizi bayi sebanyak $60 \%$ dari kebutuhan bayi usia 6-12 bulan. Sisanya harus dipenuhi dengan makanan tambahan lain yang cukup jumlahnya dan bergizi. Memberikan pelatihan pada para ibu kader Ranting Aisyiyah Tanjung Purwokerto Selatan tentang MP - ASI dan pengolahan bahan pangan local berbahan dasar daun kelor untuk MP - ASI. Follow up kegiatan dilakukan pada bulan keempat kegiatan dengan hasil monitoring ibu kader mengerti dan memahami tentang macam - macam pembuatan MP - ASI berbahan dasar daun kelor. Pentingnya pengabdian pada masyarakat ini yaitu meningkatnya pengetahuan ibu - ibu tentang MP - ASI secara umum dan pemanfaatan MP - ASI berbahan dasar lokal daun kelor.
\end{abstract}

Kata kunci: daun kelor; MP -ASI; gizi balita.

\begin{abstract}
MP - ASI is a trantition process from mik to semi - solid food. MP - ASI should be introduced and given gradually in both form and amount, according to the child's digestive ability. Breast feeding only meets the nutritional needs of infants as much as $60 \%$ of the needs of infants aged 6 12 months. The rest must be met with other complementary foods that are sufficient in numbe and nutritious. Provide training to cadres of Ranting Aisyiyah Tanjung Purwokerto Selatan on MP ASI. Follow up activities were carried out in the fourth month of activity with the resuluts of morning tha the cadre mothers understood the various kinds of making MP - ASI made from Moringa leaves. The importance of this community service is increasing knowledge of mothers about MP - ASI in general and the use of MP - ASI made from local Moringa leaves.
\end{abstract}

Keywords: moringa leaves; $M P$ - ASI; toddler nutrition. 


\section{Pendahuluan}

Daun kelor merupakan salah satu bagian dari tanaman kelor yang telah banyak diteliti kandungan gizi dan kegunaannya. Daun kelor sangat kaya akan nutrisi, diantaranya kalsium, besi, protein, vitamin $\mathrm{A}$, vitamin B dan vitamin. ${ }^{[1]}$ Daun kelor mengandung zat besi lebih tinggi daripada sayuran lainnya yaitu sebesar 17,2 mg/100 g [2], sehingga dapat mencegah anemia khususnya pada ibu hamil. ${ }^{\text {[3] }}$ MPASI merupakan proses peralihan dari susu menuju ke makanan yang semi padat. MP-ASI harus diperkenalkan dan diberikan secara bertahap baik bentuk maupun jumlahnya, sesuai dengan kemampuan pencernaan anak. ASI hanya memenuhi kebutuhan gizi bayi sebanyak $60 \%$ dari kebutuhan bayi usia 6-12 bulan. Sisanya harus dipenuhi dengan makanan tambahan lain yang cukup jumlahnya dan bergizi. Oleh sebab itu, pada usia 6 bulan keatas bayi membutuhkan tambahan gizi lain yang berasal dari MP-ASI. ${ }^{[4]}$

Berdasarkan hasil penelitian, diketahui kadar lemak dari keempat formula dibandingkan dengan MPASI komersial menunjukkan beda nyata yang artinya penambahan tepung daun kelor mempengaruhi kandungan lemak setiap formula. MP-ASI Bubuk instan campuran tepung kecambah kacang hijau dan tepung daun kelor memiliki kandungan lemak yang tinggi. Bahkan lebih tinggi daripada MPASI komersial.Hasil pengujian kimia kandungan lemak MP-ASI bubuk instan campuran tepung kecambah kacang hijau dan tepung daun kelorsebesar $13 \mathrm{~g}$ per $100 \mathrm{~g}$ bahan formula. Bila dibandingkan dengan standar kandungan lemak makanan pendamping ASI berdasarkan SNI maka kandungan lemak MP-ASI bubuk instan campuran tepung kecambah kacang hijau dan tepung daun kelor sudah memenuhi standar.Hasil penelitian ini lebih tinggi jika dibandingkan dalam peneltian sebelumnya yaitu 3,57\%. [5] Sedangkan hasil kadar lemak tepung daun kelor adalah $11,76 \%$, nilai yang dihasilkan lebih rendah jika dibandingkan dengan hasil penelitian sebelumnya yaitu $17,71 \%$. ${ }^{[6]}$

Stunting masih menjadi masalah gizi kronis di Indonesia, sehingga melalui Program Rencana Pembangunan Jangka Menengah Nasional (RJPM) pemerintah menargetkan pada tahun 2025 akan mengurangi $40 \%$ jumlah balita pendek. Untuk mencapai target tersebut pada tahun 2017 pemerintah Indonesia meluncurkan program penanggulangan stunting tingkat nasional dengan prioritas penanganan masalah gizi spesifik dan sensitif pada 1000 hari pertama kehidupan sampai dengan usia 6 tahun. Stunting disebabkan kurangnya asupan gizi dalam waktu cukup lama, sehingga mengakibatkan gangguan pertumbuhan pada anak yaitu ditandai dengan tinggi badan anak lebih rendah dari standar usianya. Dampak lain dari stunting adalah gangguan perkembangan, kesehatan, dan produktivitas, sehingga jika tidak ditangani akan menimbulkan masalah yang lebih besar, dan bangsa Indonesia dapat mengalami lost generation. [7] [8] [9]

Masa Balita adalah the point of no return. Kekurangan gizi pada masa Balita akan dapat menyebabkan gangguan serius bagi perkembangan otak yang mengakibatkan tingkat kecerdasan 
anak terhambat, dimana $80 \quad \%$ pertumbuhan otak terjadi pada masa itu. Belum lagi hambatan pada pertumbuhan fisik dan sistem kekebalan tubuh yang tidak sempurna. hal ini menyebabkan mereka menjadi generasi yang hilang (lost generation) dan negara kehilangan sumber daya manusia yang berkualitas.

\section{Metode}

\section{Kegiatan-kegiatan yang} dilaksanakan pada tahap perencanaan adalah sebagai berikut:

a. Melakukan pendekatan pada instansi terkait dan stake holder. Pendekatan dilakukan dengan cara mengirim surat permohonan ijin pengabdian kepada Ketua Aisyiyah Ranting Tanjung Purwokerto Selatan. Melakukan identifikasi permasalahan dengan cara melakukan pendataan kebutuhan ibu - ibu. Data inilah yang menjadi dasar dalam penentuan rencana tindakan berikutnya.

b. Penyusunan program pemanfaatan daun kelor dan pemberdayaan pengolahan bahan pangan, meliputi penyampaian materi, dan tanya jawab serta demonstrasi/praktik pembuatan makanan tambahan, melakukan evaluasi.

Prosedur Kerja dalam melaksanakan kegiatan IbM dari bulan Desember 2020 sampai dengan Maret 2021, pelaksana membagi menjadi beberapa tahapan atau prosedur kerja, yaitu:

a. Memberikan Pendidikan Kesehatan pada ibu kader anggota Aisyiyah Ranting Tanjung Purwokerto Selatan mengenai MP - ASI secara umum dan pemanfaatan sumber daya alam daun kelor yang mudah dan murah. b. Demonstrasi pembuatan MP ASI berbahan dasar daun kelor.

c. Keberhasilan program dilakukan evaluasi.

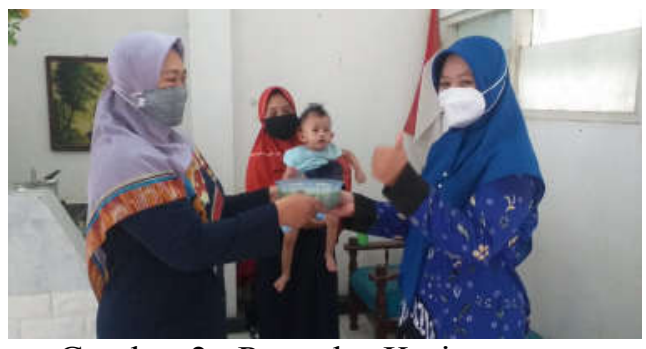

Gambar 2. Prosedur Kerja

\section{Hasil dan Pembahasan}

Latar belakang Pendidikan ibu yang mengikuti kegitan ini bervariasi yaitu terdapat ibu dengan lulusan SMP dan SMA dan tamat sarjana. Terbanyak dri tpeserta adalah tamatan SMA. Usia ibu rata - rata usia 20 - 35 tahun.

Pada awal pelatihan hasil pemberian pre test dan Ranting Aisyiyah Tanjung Purwokerto Selatan yang dilakukan, secara umum mengindentifikasikan bahwa pengolahan bahan pangan sebagai MP - ASI dengan bahan dasar daun kelor secara umum masih belum baik.

Diagram 3. Hasil Pre test dan Post tes Pengolahan Bahan Pangan untuk MP - ASI

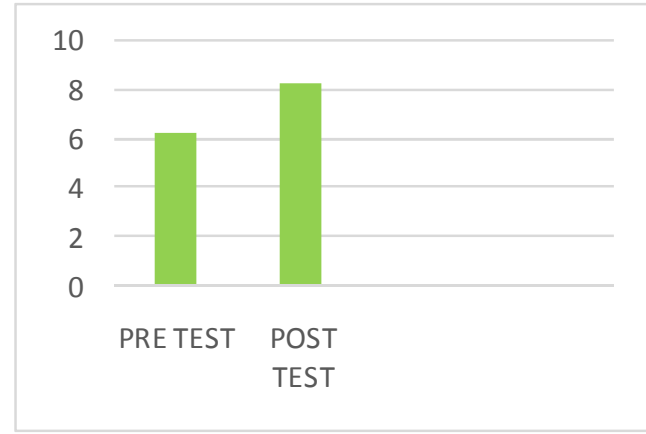

Pada awal pelatihan terdapat skor 1 karena hanya mampu menjawab satu buah pertanyaan 
akan tetapi saat post tes dilakukan dapat menjawab 7 soal dengan benar dengan skor 7,0. Hasil yang dicapai saat post tes terlihat peningkatan skor dalam menjawab soal.

Jika dilakukan perbandingan antar nilai rata - rata pre dan post test maka ada peningkatan sebesar $30 \%$. Demikian tersebut dihitung dengan melakukan perbandingan antara nilai rata - rata pre test 6,45 dan post test 8,45 .

Tingkat pendidikan juga menentukan mudah tidaknya seseorang memahami pengetahuan yang mereka peroleh, pada umumnya semakin tinggi pendidikan seseorang semakin baik pengetahuannya berdasarkan pendapat.

Pendampingan

praktik pembuatan MP - ASI berbahan dasar daun kelor untuk bayi dan balita pada kegiatan pengabdian yang dilaksanakan di Ranting Aisyiyah Tanjung Purwokerto Selatan berlangsung baik dan lancar, ibu kader mempunyai antusiasme sangat baik.

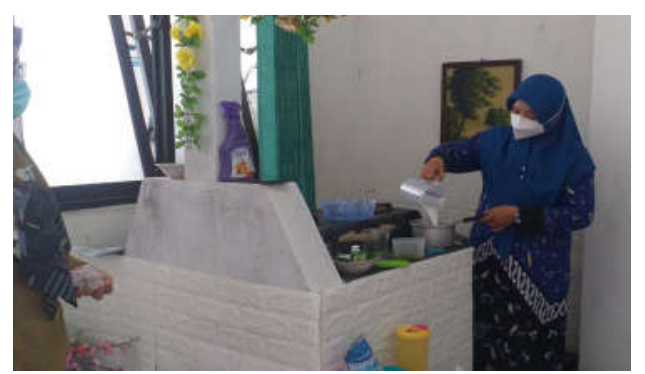

Gambar 3.1 Pendampingan praktik pembuatan MP - ASI

Ibu kader Ranting Aisyiyah Tanjung Purwokerto Selatan sangat bersemangat dan antusias saat pelaksanaan kegiatan. Ditunjukkan dengan banyaknya pertanyaan mengenai macam - macam pengolahan daun kelor sebagai MP - ASI dan menginginkan adanya pembuatan variasi lain dalam pembuatan MP - ASI dengan bahan lokal daun kelor yang mudah dan murah.

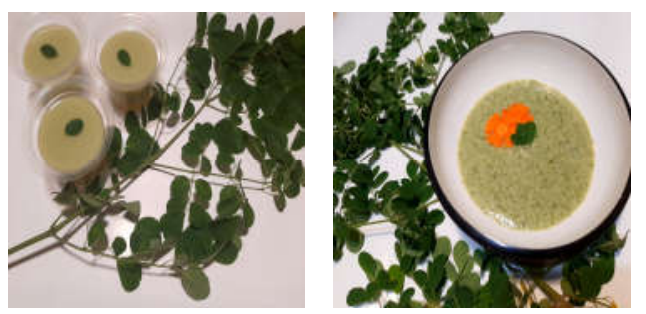

Gambar 3.2 MP-ASI

Semakin baiknya pemahaman ibu mengenai pembuatan MP - ASI berbahan dasar daun kelor maka dapat mengembangkan dan menjamin nilai gizi yang terkandung dalam daun kelor sebagai bahan dasar MP - ASI.

\section{Kesimpulan}

Berdasakan hasil evaluasi yang dilakukan, maka dapat disimpulkan sebagai berikut: Pemahaman ibu kader Ranting Aisyiyah Tanjung Purwokerto Selatan meningkat melalui pemberian materi MP ASI secara umum dan daun kelor sebagai MP - ASI. Pemahaman ibu kader Ranting Aisyiyah Tanjung Purwokerto Selatan mengalami peningkatan dengan demonstrasi dan praktik langsung pembuatan MP - ASI berbahan dasar lokal daun kelor. 


\section{Daftar Pustaka}

[1] Oluduro AO, Aderiye BI. Effect of Moringa oleifera seed extract on vital organs and tissue enzymes activities of male albino rats. Afr. J. Microbiol. Res 2009; 3:537-540. 2009.

[2] W. C. Yameogo, D. M. Bengaly, A. Savodogo, P. A. Nikiema, and S. A. Traore, "Determination of Chemical Composition and Nutritional values of moringa oleifera Leaves," Pakistan J. Nutr., vol. 10, no. 3, pp. 264-268, 2011.

[3] H. V. Nadimin, S. As'ad, and A. Buchari, "The Extract of Moringa Leaf Has an Equivalent Effect to Iron Folic Acid in Increasing Hemoglobin Levels of Pregnant Women: A randomized Control Study in the Coastal Area of Makassar," Int. J. Sci. Basic Appl. Res. 2015, vol. 22, no. 1, pp. 287-294, 2015.

[4] L. Mufida, T. D. Widyaningsih, and J. M. Maligan, "Prinsip Dasar Makanan Pendamping Air Susu Ibu ( MP-ASI ) untuk Bayi 6 - 24 Bulan Kajian Pustaka. Basic Principles of Complementary Feeding for Infant 6 - 24 Months : A Review," J. Pangan dan Agroindustri, vol. 3, no. 4, pp. 1646-1651, 2015.
[5] Emma A. Husna, Dian Rachmawanti Affandi, Kawiji, R. B. K. A. 'Karakterisasi Bubur Bayi Instan Berbahan Dasar Tepung Millet (Panicum Sp) Dan Tepung Kacang Hijau (Phaseolus Radiatus) Dengan Flavor Alami Pisang Ambon (Musa paradisiaca var. Sapientum 1.) STUDY', Jurnal Teknosains Pangan, 1(1). 2012.

[6] Kustiani, Pengembangan crackers sumber protein dan mineral dengan penambahan tepung daun kelor (Moringa oleifera) dan tepung badan kepala ikan lele dumbo (Clarias gariepinus). Institute Pertanian Bogor, 2013.

[7] U. Laili and R. A. D. Andriani, "Pemberdayaan masyarakat Dalam Pencegahan Stunting," $J$. Pengabdi. Masy. Ipteks, vol. 5, no. 1, 2019.

[8] T. A. Putri, "Faktor Risiko Kejaidan Stunting Pada Balita Kotagede I Kota Yogyakarta Tahun 2018 Faktor Risiko Kejadian Stunting Pada Balita Usia 25 - 59 Bulan Di Wilayah Puskesmas Kotagede I Kota Yogyakarta. Skrips. Sarjan Terapan Kebidanan," Politeknik Kesehatan Kementrian Kesehatan Yogyakarta, Yogyakarta, 2018.

[9] World Health Organization (WHO), World Healt Statistic. 2018.

[10] A. Hasanah, Pengembangan Profesi Guru. Bandung: CV. Pustaka Setia, 2012. 